DIW BERLIN

Discussion

Papers
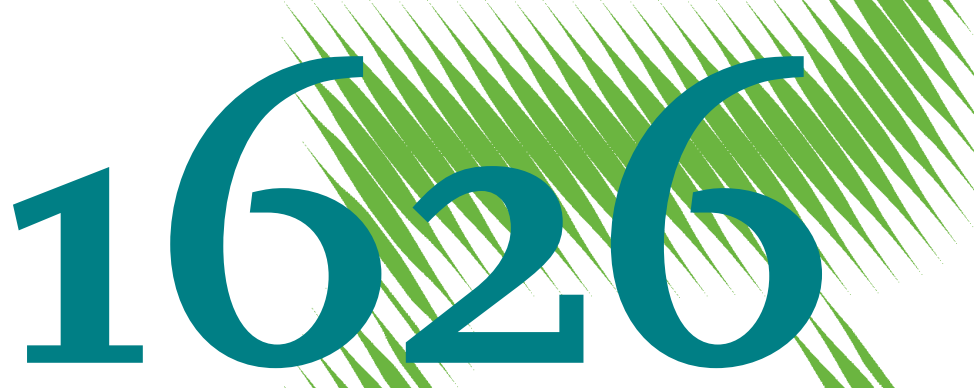

MIM
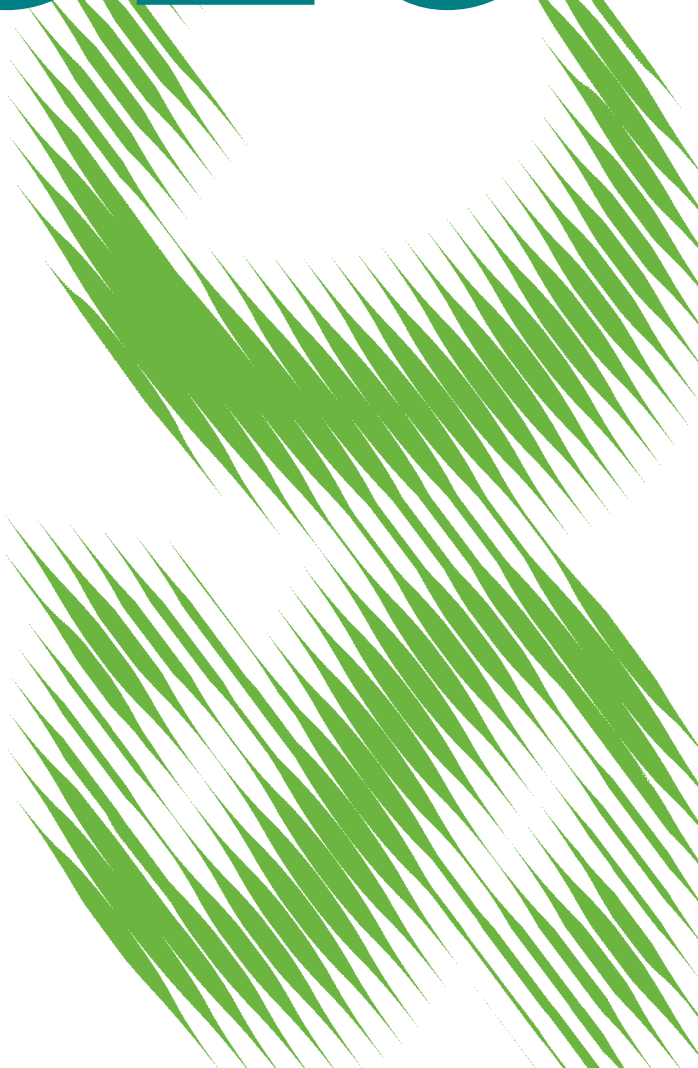

The Macroeconomic Effects of Progressive Taxes and Welfare 
Opinions expressed in this paper are those of the author(s) and do not necessarily reflect views of the institute.

IMPRESSUM

(C) DIW Berlin, 2016

DIW Berlin

German Institute for Economic Research

Mohrenstr. 58

10117 Berlin

Tel. +49 (30) $89789-0$

Fax +49 (30) $89789-200$

http://www.diw.de

ISSN electronic edition 1619-4535

Papers can be downloaded free of charge from the DIW Berlin website:

http://www.diw.de/discussionpapers

Discussion Papers of DIW Berlin are indexed in RePEc and SSRN:

http://ideas.repec.org/s/diw/diwwpp.html

http://www.ssrn.com/link/DIW-Berlin-German-Inst-Econ-Res.html 


\title{
The Macroeconomic Effects of Progressive Taxes and Welfare
}

\author{
Philipp Engler and Wolfgang Strehl*†
}

November 25, 2016

\begin{abstract}
We analyze the positive and normative effects of a progressive tax on wages in a nonlinear New Keynesian DSGE model in the presence of demand and technology shocks. The non-linearity allows us to disentangle the effects of the progressive tax on the volatility and the level of macroeconomic variables, for both intertemporally optimizing ("Ricardian") and non-Ricardian ("rule-of-thumb") households. We find that the interaction of the two household types is of crucial importance. When only Ricardian households are considered, progressive taxes increase welfare (compared to flat taxes) in the presence of technology shocks. Aggregate welfare falls, however, when rule-of-thumb households are added to the analysis. The progressive tax increases the welfare of the latter household by lowering its consumption volatility, but this is overcompensated for by the destabilization of Ricardian household consumption. Under demand shocks, progressive taxes reduce the welfare of both household types, with the welfare of rule-of-thumb households falling despite a decline in their consumption volatility. The reason is a lower average consumption level which is related to the changed curvature of the marginal cost function.
\end{abstract}

Keywords: Progressive Taxation, Rule-of-thumb Households, Monetary Policy JEL classification: E2, E3, E52, E62

*Philipp Engler: DIW Berlin, address: Mohrenstr. 58, 10117 Berlin, Germany, tel: +49-30-89789486, email: pengler@diw.de. Wolfgang Strehl: Freie Universität Berlin, address: Lansstr. 7-9, 14195 Berlin, Germany, tel: +49-30-83862909, email: w.strehl@fu-berlin.de.

${ }^{\dagger}$ A special thanks goes to Simon Voigts for helping with some of the programming. We also thank participants at Freie Universität Berlin, University of Potsdam, University of Osnabrück, Queensland University of Technology, DIW Berlin, the 2015 Verein für Socialpolitik Annual Conference, the 2015 Asymmetries in Europe workshop in Pescara, the 2015 European Integration workshop in Köln, and the 2015 EEFS Conference in Brussels for valuable comments and suggestions. Any remaining errors are, of course, ours. An earlier version of the paper circulated under the name "Progressive Taxation and Monetary Policy in a Currency Union". 


\section{Introduction}

Progressive taxes are one of the instruments by which fiscal policies aim at automatically stabilizing the business cycle (Auerbach and Feenberg 2000). The traditional, demand side argument for them is based on progressive income taxes' effects on disposable income (Brown 1955): They reduce the volatility of the latter compared to the volatility of the market income and thereby stabilize aggregate demand and output. In modern DSGE models, in contrast, where households' intertemporal optimization renders disposable income irrelevant for aggregate demand, the stabilization properties occur through the supply side (Mattesini and Rossi 2012).

In this paper, we add to the debate on the effects of progressive taxes by jointly analyzing the demand side and supply side business cycle effects, as well as the resulting welfare implications, using a non-linear DSGE framework calibrated to the euro area. ${ }^{1}$ We do so by introducing a fraction of "rule-of-thumb" households and a progressive wage tax into an otherwise standard New Keynesian DSGE model. The rule-of-thumb households consume their entire disposable income so that the progressive tax reduces their consumption volatility, in line with the traditional demand side view. The remaining fraction of households are "Ricardian" in the sense that they optimize consumption intertemporally based on their lifetime income and thus do not react to changes in disposable income caused by tax progression. However, their (and the rule-of-thumb households') labor supply decision is affected by the progressivity of the tax rate in that the labor supply elasticity is reduced. This implies that firms' marginal cost curves become steeper resulting in a different price setting behavior compared to a flat tax (Mattesini and Rossi 2012).

Our first main finding is that in a baseline scenario without rule-of-thumb households, progressive taxes are desirable from a welfare perspective when only technology shocks drive the business cycle. Ricardian welfare rises when progressive taxes are introduced (instead of flat taxes) because the supply side effects cause the volatility of inflation to fall. As the central bank follows a Taylor-type rule in our model, the volatility of the real interest rate falls and with it the volatility of Ricardian households' consumption. This latter effect increases Ricardian welfare. The reduction in the inflation volatility is caused by the steeper marginal cost curve which reduces the price reaction of firms in the presence of technology shocks.

\footnotetext{
${ }^{1}$ We focus on the euro area because tax progression is more pronounced there than e.g. in the United States. See Mattesini and Rossi (2012) for a comparison of the degree of tax progression across countries.
} 
However, once rule-of-thumb households are also considered, our analysis shows that the interaction between the two household types crucially affects the welfare implications of the tax system. Rule-of-thumb households' welfare indeed rises when progressive taxes are introduced because their consumption volatility is significantly reduced. Ricardian households' welfare, in contrast, falls strongly. This is because the reduced consumption volatility of rule-of-thumb households increases the volatility of inflation in the presence of technology shocks. This, in turn, increases the volatility of the real interest rate which leads to an increasing volatility of Ricardian consumption. As economy-wide welfare falls for our model calibration, our second main finding is that progressive taxes can no longer be justified on utilitarian grounds once both the supply side and the demand side effects of progressive taxes are taken into account.

Our third main finding is that when only demand shocks drive the business cycle, economywide welfare falls after the introduction of progressive taxes. This holds for both the baseline model as well as the model with rule-of-thumb households. Specifically, Ricardian households are worse off in both scenarios because the steeper marginal cost curve under progressive taxes increases the volatility of inflation in the presence of demand shocks and thus the volatility of their consumption. In addition, and somewhat surprisingly, we find that even rule-of-thumb households are worse off. This is despite their lower consumption volatility, which is also achieved in this setting. But another effect dominates here which is related to the non-linearity of the model: The progressive tax not only increases the slope of the marginal cost curve, it also increases its convexity. With a convex marginal cost curve, firms' price increases tend to be larger than their price decreases resulting in a higher average inflation rate compared to a setting with flat taxes. The higher average inflation rate gives rise to a higher average real interest rate and lower average Ricardian consumption. Average output falls, the latter also reducing rule-of thumb households' average consumption. This level effect holds for both technology and demand shocks and is, all other things equal, welfare-reducing. In the former case, however, this effect is dominated by the much lower consumption volatility of rule-ofthumb households whereas in the latter case, the level effect dominates. This last result shows, first, the importance of taking account of non-linearities when analyzing a non-linear tax system and, second, the importance of the interaction between the two household types.

Beyond these core findings, we present three additional results. First, we compute the 
optimal degree of tax progression for the baseline economy without rule-of-thumb households. Second, since our model is calibrated to the euro area, we show that the above results also prevail in a two-country model of a monetary union, with the main difference being that all effects are quantitatively smaller. Key for this quantitative difference is the link between tax progression and the volatility of the terms of trade. Third, we show that when only technology shocks drive the business cycle, the welfare gains in the baseline economy disappear once monetary policy is conducted optimally. Overall, our findings show that it is difficult to make the case for progressive taxes based on its business cycle effects only, especially as demand shocks rather than technology shocks presumably have a dominant impact on cyclical fluctuations. Other, most likely distributional arguments, would have to be made to justify them.

There is a large and growing literature on automatic fiscal stabilizers. ${ }^{2}$ However, to the best of our knowledge, there are only a few papers that explicitly focus on the role of progressive taxes in a DSGE context. The paper closest to ours is Mattesini and Rossi (2012). They introduce a progressive tax on wages in an otherwise standard New Keynesian DSGE model and analyze, in a linear setting, how the tax affects business cycle dynamics and the optimal conduct of monetary policy. Our main contribution relative to their paper is threefold: First, we explicitly study the welfare effects of progressive taxes whereas Mattesini and Rossi (2012) only conduct a positive analysis. Second, we take the existence of rule-of-thumb households into account and thereby add the traditional Keynesian demand-side stabilization channel of progressive taxes to the analysis. Third, we employ a non-linear model which allows us to also analyze how the progressive tax affects the levels of the macroeconomic variables of interest (in addition to their volatilities). ${ }^{3}$

McKay and Reis (2016a) is another related paper that needs to be mentioned. The authors combine a New Keynesian model in the spirit of Christiano et al. (2005) with a version of the standard incomplete markets model of Krusell and Smith (1998) and analyze the quantitative role of automatic stabilizers in the U.S. business cycle. The progressive tax system is one of many automatic stabilizers they consider. Our paper differs from theirs in one crucial way. We employ a much simpler model and focus on only one automatic stabilizer, the progressive

\footnotetext{
${ }^{2}$ See McKay and Reis (2016a) for a recent review of the literature.

${ }^{3}$ Two other papers that use the same specification for the progressive tax as Mattesini and Rossi (2012) and this paper are Chen and Guo (2013, 2014). However, they employ an RBC model and solely focus on the theoretical relationship between tax progression and equilibrium (in)determinacy.
} 
tax system. This simplification allows us to be more specific about the underlying economic mechanisms. In particular, we stress the important link between tax progression and inflation dynamics. Furthermore, we emphasize the role of the household type and household interactions in affecting key results. At last, we analyze the macroeconomic effects of progressive taxes for each shock type separately. ${ }^{4}$

Our paper is structured as follows. In Section 2, we introduce the model framework, followed by a description of the model calibration and the employed welfare measure in Section 3 . In Section 4, we analyze how progressive taxes affect the model dynamics and economic welfare. We consider two model extensions in Section 5. Section 6 concludes.

\section{The Model}

Our baseline model is the same as the one used by Mattesini and Rossi (2012): the standard New Keynesian model with a representative Ricardian household as in Galí (2008), augmented by government expenditure and a progressive tax on household labor income. In an extension to this baseline model, we allow for the presence of rule-of-thumb households as in Galí et al. (2007). Ricardian households have access to financial markets and own the firm sector while rule-of-thumb households are excluded from financial markets and hence use their entire period income for consumption purposes. Both household types supply (homogenous) labor to the firm sector taking the wage rate as given. The firm sector consists of a continuum of monopolistically competitive firms which use labor as the sole production input and set prices in a staggered manner as in Calvo (1983). An exogenous stream of government expenditure is financed by taxing wages, in a progressive fashion as in Guo and Lansing (1998), and steady state firm profits. Monetary policy follows a Taylor-type interest rate rule (Taylor 1993). In the following, letters without a time index $t$ always denote the (non-stochastic) steady state value of the respective variable.

\footnotetext{
${ }^{4}$ McKay and Reis (2016b) is another recent paper. They study the optimal degree of automatic stabilization, amongst others tax progression, in a model framework similar to McKay and Reis (2016a).
} 


\subsection{The Household Sector}

The economy is populated by a continuum of households. A fraction of households $\lambda$ consists of rule-of-thumb households while the rest $(1-\lambda)$ consists of Ricardian households. Variables related to Ricardian households are denoted with a superscript $A$ (asset-holders), those related to rule-of-thumb households are denoted with a superscript $N$ (non-asset holders).

\subsubsection{Ricardian households}

The representative Ricardian household seeks to maximize the lifetime utility given by

$$
E_{t} \sum_{k=0}^{\infty} \beta^{k}\left\{\frac{\left(C_{t+k}^{A}\right)^{1-\sigma}}{1-\sigma}-\frac{\left(N_{t+k}^{A}\right)^{1+\varphi}}{1+\varphi}\right\}
$$

subject to a sequence of flow budget constraints

$$
P_{t} C_{t}^{A}+B_{t}=R_{t-1} B_{t-1}+\left(1-\tau_{t}^{A}\right) W_{t} N_{t}^{A}+\left(\Pi_{t}-\Pi\right)-T_{t}
$$

where $C_{t}^{A}=\left(\int_{0}^{1} C_{t}(i)^{1-\frac{1}{\epsilon}} d i\right)^{\frac{\epsilon}{\epsilon-1}}$ is the Dixit-Stiglitz consumption index (with $C_{t}(i)$ denoting consumption of differentiated good $i$ sold by firm $i$ (see below) and $\epsilon$ the elasticity of substitution), $P_{t} \equiv\left(\int_{0}^{1} P_{t}(i)^{1-\epsilon} d i\right)^{\frac{1}{1-\epsilon}}$ the corresponding price index (with $P_{t}(i)$ the price of good $i), N_{t}^{A}$ hours worked, and $W_{t}$ the (nominal) wage. Prices and wages are taken as given by the household. $B_{t}$ is the beginning of period amount of a bond, $R_{t}$ is the corresponding (nominal) interest rate. $\Pi_{t}$ are firm profits (per Ricardian household). ${ }^{5} \sigma$ determines the degree of relative risk aversion and $\varphi$ the degree of labor disutility (inverse of the Frisch labor supply elasticity), $\beta$ is the subjective discount factor. Finally, the household faces a tax rate $\tau_{t}^{A}$ on wage income as well as lump-sum taxes $T_{t}$ (which are zero on average).

Following Guo and Lansing (1998), and, more recently, Mattesini and Rossi (2012), we assume that the tax schedule $\tau_{t}^{A}$ is given by

$$
\tau_{t}^{A}=1-\eta\left(\frac{Y_{n}}{Y_{n, t}^{A}}\right)^{\phi_{n}}
$$

\footnotetext{
${ }^{5}$ To simplify the analysis, the steady state value of firm profits is taxed away in our calibration (see below). Thereby we ensure that income and thus consumption levels between Ricardian and rule-of-thumb households are equalized in the steady state.
} 
where $Y_{n, t}^{A}=\frac{W_{t} N_{t}^{A}}{P_{t}}$ is the household's (current period) real wage income and where $Y_{n}=\frac{W N}{P}$ is the steady state level of real wage income. ${ }^{6}$ Note that $\eta \in(0,1]$ determines the level of the tax schedule while $\phi_{n} \in[0,1)$ determines the slope. It is easy to show (see Mattesini and Rossi 2012) that the following relationship between the marginal tax rate $\tau_{t}^{A, m}=\frac{\partial\left(\tau_{t}^{A} Y_{n, t}^{A}\right)}{\partial Y_{n, t}^{A}}$ and the average tax rate $\tau_{t}^{A}$ holds:

$$
\tau_{t}^{A, m}=\tau_{t}^{A}+\eta \phi_{n}\left(\frac{Y_{n}}{Y_{n, t}^{A}}\right)^{\phi_{n}}
$$

Accordingly, the marginal tax rate is higher than the average tax rate whenever $\phi_{n}>0$. In this case the tax schedule will be referred to as "progressive" since the average tax rate increases in income. When $\phi_{n}=0$ the marginal tax rate coincides with the average tax rate and the tax schedule will be referred to as "flat".

The Ricardian household's first-order conditions are next given by

$$
\begin{aligned}
\left(N_{t}^{A}\right)^{\varphi+\phi_{n}} & =\left(C_{t}^{A}\right)^{-\sigma}\left(\frac{W_{t}}{P_{t}}\right)^{1-\phi_{n}} \eta\left(1-\phi_{n}\right)\left(\frac{W N}{P}\right)^{\phi_{n}} \\
1 & =\beta E_{t}\left\{\left(\frac{C_{t+1}^{A}}{C_{t}^{A}}\right)^{-\sigma} \frac{P_{t}}{P_{t+1}} R_{t}\right\}
\end{aligned}
$$

where the first condition determines the household's labor supply and where the second condition is a standard consumption Euler equation. We can see from equation (2) that the progressive labor tax mitigates the response of hours worked to a change in the real wage holding consumption constant. Put differently, the labor supply schedule becomes steeper as an increase in hours necessitates a stronger increase in real wages because an increasing fraction of the gross real wage is taxed away. We will see below that progressive taxes can hereby potentially act as an automatic stabilizer on the supply side of the economy. ${ }^{7}$

Further note that progressive taxation also affects the steady state labor supply (and thus aggregate output) according to equation (2). A higher degree of tax progression implies a lower labor supply. Since in this paper we are interested in the business cycle properties of

\footnotetext{
${ }^{6}$ Note that steady state real wage income does not differ between Ricardian and rule-of-thumb households. Also note that we assume flexible wages. The Calvo model that we use for prices would imply a continuum of wages and thus by equation (1) a continuum of household tax rates thereby considerably complicating the analysis.

${ }^{7}$ See Mattesini and Rossi (2012). Automatic stabilization on the supply side has been previously stressed by e.g. Auerbach and Feenberg (2000).
} 
tax progression, we eliminate the steady state effect of tax progression through the use of an appropriate employment subsidy for the firm sector when we simulate the model subsequently. ${ }^{8}$ The policy-invariant steady state considerably facilitates our analysis.

\subsubsection{Rule-of-thumb households}

In a variant of the model, we allow for a certain fraction of households who do not optimize their utility intertemporally. Those rule-of-thumb households have the same preferences with respect to consumption and hours worked as Ricardian households but lack access to financial markets. The representative rule-of-thumb household's labor supply is thus governed by an equation equivalent to (2) while its consumption expenditures are fully pinned down by its current disposible income:

$$
P_{t} C_{t}^{N}=\left(1-\tau_{t}^{N}\right) W_{t} N_{t}^{N}
$$

It is important to note that the progressive labor $\operatorname{tax} \tau_{t}^{N}$ has an immediate stabilizing effect on rule-of-thumb households' consumption through dampening the fluctuations of disposable income. ${ }^{9}$ All other things equal, due to the presence of credit constrained households, the progressive tax system thus also acts as an automatic stabilizer on the demand side of the economy. ${ }^{10}$

\subsection{The Government}

\subsubsection{Fiscal policy}

We follow Mattesini and Rossi (2012) and assume that the government pursues a balanced budget rule. ${ }^{11}$ The fiscal authority finances an exogenous stream of (stochastic) government

\footnotetext{
${ }^{8}$ The subsidy (per unit of labor employed) would correspond to the value of the coefficient $\phi_{n}$. To see this, note that firm optimization implies $\frac{W}{P}=\frac{M P L}{M_{p}}$ where $M P L$ denotes the marginal product of labor and $M_{p} \equiv \frac{\epsilon}{\epsilon-1}$ is the price markup. With an employment subsidy $\tau^{s}$, the optimality condition would read $\frac{W}{P}\left(1-\tau^{s}\right)=\frac{M P L}{M_{p}}$ instead. Setting $\tau^{s}=\phi_{n}$, it follows that $\frac{W}{P}=\frac{M P L}{M_{p}}\left(1-\phi_{n}\right)^{-1}$ which implies, according to (2), that household labor supply is independent of the value of $\phi_{n}$. Note, however, that the subsidy does not eliminate the steady state distortion that stems from monopolistic competition and (flat) income taxation.

${ }^{9}$ The functional form of the tax schedule is equivalent to that of Ricardian households.

${ }^{10}$ Mattesini and Rossi (2012) do not capture this demand side stabilization effect.

${ }^{11}$ Recall that we assumed, not unrealistically, that rule-of-thumb households do not pay lump-sum taxes. Ricardian households, however, do. Yet note that allowing instead for government debt holdings of Ricardian households is equivalent with the latter assumption since Ricardian equivalence holds. Using the lump-sum tax
} 
consumption $G_{t}$ by way of taxing household wage income, by imposing lump-sum taxes on Ricardian households, and by taxing (away) the steady state profits of firms. ${ }^{12}$ Accordingly, the period budget constraint of the government is given by

$$
P_{t} G_{t}=(1-\lambda) W_{t} N_{t}^{A} \tau_{t}^{A}+\lambda W_{t} N_{t}^{N} \tau_{t}^{N}+T_{t}+\Pi
$$

\subsubsection{Monetary policy}

We use a Taylor-type interest rate rule (Taylor 1993) in the baseline model. The rule targets price inflation and is given by

$$
R_{t}=\beta^{-1}\left(\frac{P_{t}}{P_{t-1}}\right)^{\phi_{\pi}}
$$

where $\phi_{\pi}>1$.

We also consider Ramsey-optimal monetary policy in an extension to the baseline model.

\subsection{The Firm Sector}

\subsubsection{Production}

Monopolistically competitive firm $i$ produces the differentiated good $Y_{t}(i)$ according to

$$
Y_{t}(i)=A_{t} N_{t}(i)
$$

where $N_{t}(i)$ is the labor input of firm $i$ and $A_{t}$ the (stochastic) level of technology common to all firms. The production function implies that (real) marginal costs $R M C_{t}$ are equalized across firms, i.e.

$$
R M C_{t}(i)=R M C_{t}=\frac{W_{t}}{P_{t}} A_{t}^{-1}
$$

As discussed above, the progressive income tax implies a larger real wage increase for any given increase in employment. This in turn raises marginal costs more. Hence, the marginal cost curve, just like the labor supply curve, becomes steeper when taxes are progressive. Below

${ }^{12} G_{t}$ is defined analogously to the private consumption aggregate $C_{t}$. 
we will see that the marginal cost curve also becomes more convex with progressive taxes thereby crucially influencing incentives for price setting.

\subsubsection{Price setting}

Firms set prices in a staggered fashion as in Calvo (1983) taking the demand functions for their good as given. Each period, a randomly drawn fraction of firms $\theta_{p}$ is not able to reset their prices while the remaining fraction $\left(1-\theta_{p}\right)$ is able to do so. The first-order condition for readjusting firms with respect to the price chosen $P_{t}^{o}$ is standard and given by

$$
\sum_{k=0}^{\infty} \theta_{p}^{k} E_{t}\left\{Q_{t, t+k}\left(\frac{P_{t}^{o}}{P_{t+k}}\right)^{-\epsilon-1} Y_{t+k}\left[\frac{P_{t}^{o}}{P_{t+k}}-\frac{\epsilon}{\epsilon-1} R M C_{t+k}\right]\right\}=0
$$

where $Q_{t, t+k}=\beta E_{t}\left\{\left(\frac{C_{t+k}^{A}}{C_{t}^{A}}\right)^{-\sigma} \frac{P_{t}}{P_{t+k}}\right\}$ is the (Ricardian) household's stochastic discount factor ${ }^{13}$ and $Y_{t}=\left[\left(Y_{t}(i)\right)^{\frac{\epsilon-1}{\epsilon}} d i\right]^{\frac{\epsilon}{\epsilon-1}}$ gross domestic product (GDP).

\subsection{Equilibrium and Aggregation}

Equilibrium in the labor market implies

$$
N_{t}=\int_{0}^{1} N_{t}(i) d i
$$

Bond market clearing implies $B_{t}=0 \forall \mathrm{t}$.

The goods market is in equilibrium when supply equals demand for all goods $i \in[0,1]$, i.e.

$$
Y_{t}(i)=C_{t}(i)+G_{t}(i)
$$

In turn, GDP is obtained by aggregating consumption demand and government expenditure:

$$
Y_{t}=C_{t}+G_{t}
$$

\footnotetext{
${ }^{13}$ Because firms are owned by Ricardian households they also use the same discount factor.
} 
The aggregate supply side is summarized by

$$
Y_{t}=s_{t}^{-1} A_{t} N_{t}
$$

where $s_{t} \geq 1$ is given by the difference equation (see Schmitt-Grohé and Uribe 2006)

$$
s_{t}=\left(1-\theta_{p}\right)\left(\widetilde{p}_{t}\right)^{-\epsilon}+\theta_{p}\left(1+\pi_{t}\right)^{\epsilon} s_{t-1}
$$

with $\widetilde{p_{t}} \equiv \frac{P_{t}^{o}}{P_{t}}$ and where $\pi_{t}$ denotes price inflation. The variable $s_{t}$ represents a resource cost induced by inefficient price dispersion across firms if the value exceeds one. ${ }^{14}$

Under the Calvo mechanism the evolution of aggregate prices is finally given by the law of motion

$$
1=\theta_{p}\left(1+\pi_{t}\right)^{-1+\epsilon}+\left(1-\theta_{p}\right) \widetilde{p}_{t}^{1-\epsilon}
$$

This last equation could be combined with the price-setting first order condition (7) to obtain the economy's Phillips curve. Progressive taxes, due to the stronger impact of an increase in employment on marginal costs discussed above, lead to a steeper Phillips curve. That is, a given positive (negative) deviation of output from its flexible price equivalent leads to a larger inflationary (deflationary) response. This was first shown by Mattesini and Rossi (2012). ${ }^{15}$

Finally, the equilibrium real marginal cost function is important for understanding aggregate price dynamics too. For our baseline model without rule-of-thumb households this can be derived by combining the real marginal cost function (6) with first order condition (2) and the aggregate demand and supply relations (8) and (9):

$$
R M C_{t}=\left(s_{t} Y_{t}\right)^{\frac{\varphi+\phi_{n}}{1-\phi_{n}}}\left(Y_{t}-G_{t}\right)^{\frac{\sigma}{1-\phi_{n}}} A_{t}^{-\frac{1+\varphi}{1-\phi_{n}}} \text { const. }
$$

The progressive tax system thus increases the degree of convexity of the marginal cost

\footnotetext{
${ }^{14}$ As these resource costs costs are related to the volatility of inflation (see e.g. Woodford (2003) for the relationship between price dispersion and inflation), a reduction of this volatility has an effect like a permanent increase in productivity.

${ }^{15}$ Mattesini and Rossi (2012) derive the Phillips curve for the case of tax progression in a linearized model. We do not illustrate the Phillips curve as we are interested in a second order approximation of the model equations.
} 
function in output and productivity. This will turn out to have important implications for both the volatility and average level of prices as we will discuss in section 4 .

\section{Calibration, Simulation, and Welfare Measure}

The model is solved using Dynare++ (Kameník 2011). We employ a second-order approximation of the equilibrium conditions to capture the non-linearity of the real marginal cost function. ${ }^{16}$ The exogenous processes considered are technology and government spending shocks.

\subsection{Calibration}

The calibration is based on the assumption that the relevant time period is one quarter. The baseline parameterization employed looks as follows: the household's subjective discount factor $\beta$ is set to 0.99 which is consistent with a steady state value of the real interest rate of approximately 4 percent. The values $\sigma=1$ (log utility of consumption) and $\varphi=1$ (unitary Frisch elasticity of labor supply) for the household's utility function are standard in the literature. When considering rule-of-thumb households, we set their share in the population to 50 percent $(\lambda=0.5)$ as in Galí et al. (2007). This value is within the range of estimated values found in the literature (see Mankiw 2000). In settings where we abstract from rule-of-thumb households, we set $\lambda=0 .{ }^{17}$ The elasticity of substitution between goods $\epsilon$ takes a value of 9 , implying a steady state gross price markup of size 1.125. Finally, the degree of price rigidity is given by $\theta_{p}=2 / 3$, i.e. the average duration of prices is assumed to be 3 quarters.

Turning to the fiscal and monetary policy parameters, we assume that $\eta=0.84375$ which amounts to a steady state average tax rate on wage income of roughly 16 percent. In our model economy this value is consistent with a government spending share of 25 percent in GDP if steady state profit income is entirely taxed away by the government and steady state lump-sum taxes are zero. The tax progressivity parameter $\phi_{n}$ either takes the value 0 (flat tax) or 0.34

\footnotetext{
${ }^{16}$ As noted above, we are interested in how an optimal conduct of monetary policy affects our results. The current version of Dynare (4.4.3) only allows a first order approximation of the equilibrium conditions when using the optimal policy command. We therefore use Dynare ++ for all simulations. However, the impulse responses shown below for the specifications with Taylor rules were generated by Dynare 4.4.3. We checked and verified that this is inconsequential for the results.

${ }^{17} \mathrm{As}$ is well known in the literature, the existence of rule-of-thumb households shrinks the determinacy region of the model (see e.g. Galí et al. (2004)). Mattesini and Rossi (2012) show that progressive taxes also have this property. For our baseline calibration, indeterminacy occurs under flat taxes when $\lambda>0.61$ and under progressive taxes when $\lambda>0.56$.
} 
(the GDP-weighted average observed for the EA-12, based on the computations of Mattesini and Rossi 2012). For the Taylor inflation coefficient $\phi_{\pi}$ we choose the standard value 1.5. ${ }^{18}$

\subsection{Exogenous Processes}

The exogenous processes considered in the following are technology and government spending shocks. The shocks are specified as $\mathrm{AR}(1)$ processes, i.e. $a_{t}=\rho_{a} a_{t-1}+\epsilon_{a, t}$ where $a_{t}=\ln \left(A_{t}\right)$ and $g_{t}=\rho_{g} g_{t-1}+\epsilon_{g, t}$ where $g_{t}=\ln \left(\frac{G_{t}}{G}\right)$. The autocorrelation coefficient $\rho_{a}$ takes the value 0.95, $\rho_{g}$ takes the value 0.66 . The standard deviations of the innovations $\epsilon$ are chosen so as to match the observed volatility of GDP and government purchases in the Euro area. The values are 0.00365 for technology shocks and 0.0062 for government spending shocks. For each model specification, we ran 5 simulations with 200000 periods each.

\subsection{Welfare Measure}

Our welfare measure is expected household lifetime utility which is converted into a convenient consumption loss equivalent in the spirit of Lucas (1987). More precisely, for each combination of fiscal and monetary policy regimes, we solve for the variable $\xi^{r e g}$ of the following equation:

$$
E_{t} \sum_{k=0}^{\infty} \beta^{k} U\left(C\left(1-\xi^{r e g}\right), N\right)=E_{t} \sum_{k=0}^{\infty} \beta^{k} U\left(C_{t+k}, N_{t+k}\right)
$$

$\xi^{r e g}>0$ represents the percentage reduction in average consumption in the non-stochastic steady state that makes households indifferent between living in this deterministic state of the world (with reduced average consumption) and the stochastic state of the world under the respective monetary and fiscal policy combination. For our model parameterization, this consumption equivalent is given by

$$
\xi^{r e g}=100\left(1-\exp \left(\left(W^{r e g}-W\right)(1-\beta)\right)\right)
$$

where $W^{r e g}$ is unconditional welfare computed under one particular fiscal and monetary policy combination in a stochastic environment and $W$ is welfare in the non-stochastic steady state. ${ }^{19}$

\footnotetext{
${ }^{18}$ Estimating a reaction function for the ECB, Hayo and Hofmann (2006) find a Taylor inflation coefficient of roughly 1.5 for expected inflation.

${ }^{19}$ See also Benes and Kumhof (2011) for a recent application. When considering both household types,
} 
When considering the household utility function, it should be obvious that the realization of $\xi^{\text {reg }}$ depends on both the levels of consumption and employment as well as their volatilities. ${ }^{20}$

\section{Progressive Taxation and Welfare}

In this chapter, we analyze the business cycle and welfare effects of a progressive tax on labor income. To build intuition, we sketch the macroeconomic effects of tax progression in a static setup first — taking the perspective of a representative monopolistic firm — before considering the fully-fledged dynamic model economy.

\subsection{Intuition: Macroeconomic Effects of Progressive Taxation}

How does the progressive tax system affect the cyclical behavior of the most closely observed macroeconomic variables inflation, real GDP, and employment? To answer this question, let us consider the pricing and production decision of an arbitrary monopolistically competitive firm that has the possibility to adjust its price in the current period. Figure 1 first sketches, in a static and linear setup, the (optimal) response of the firm to technology shocks and the resulting fluctuations of prices and real activity for a flat and a progressive tax system. Figure 2 does the same for a government spending shock. Two types of effects need to be differentiated: first, the influence of progressive taxes on the volatility of the relevant variables (illustrated graphically in Figures 1 and 2), and, second, the influence of tax progression on average prices (not illustrated). We will show that the volatility effects are different for the two shock types while the level effect on prices is the same.

As can be seen in Figure 1 (and as described above), progressive taxes imply, relative to flat taxes, that the firm's marginal cost curve is steeper. Holding demand $D$ constant $^{21}$,

we compute the consumption loss equivalents $\xi^{A, r e g}=100\left(1-\exp \left(\left(W^{A, r e g}-W\right)(1-\beta)\right)\right)$, $\xi^{N, r e g}=$ $100\left(1-\exp \left(\left(W^{N, r e g}-W\right)(1-\beta)\right)\right)$, and $\xi^{r e g}=100\left(1-\exp \left(\left(\left(\left(1-\lambda_{n}\right) W^{A, r e g}+\lambda_{n} W^{N, r e g}\right)-W\right)(1-\beta)\right)\right)$. Evidently, $\xi^{r e g} \neq\left(1-\lambda_{n}\right) \xi^{A, r e g}+\lambda_{n} \xi^{N, r e g}$. In this case, $\xi^{\text {reg }}$ is to be interpreted as the reduction in steady state consumption that makes a hypothetical household that does not have any prior knowledge of his type (A or $\mathrm{N}$ ) indifferent between the stochastic and the non-stochastic world.

${ }^{20}$ We thereby deviate from the common practice of expressing welfare in terms of inflation and an output gap term and thereby propose a somewhat different perspective on welfare without changing any of the core mechanisms.

${ }^{21}$ This assumption seems plausible when rule-of-thumb households are absent. Note that in any given period, Ricardian households consume a fraction of their total expected lifetime resources. A temporary technology shock that changes their lifetime resources should thus only have a small effect on their current period consumption demand. In contrast, rule-of-thumb households base their consumption on current period resources. Their consumption demand should thus be significantly affected by technology shocks. 
Figure 1: Technology shocks and volatility of output and prices

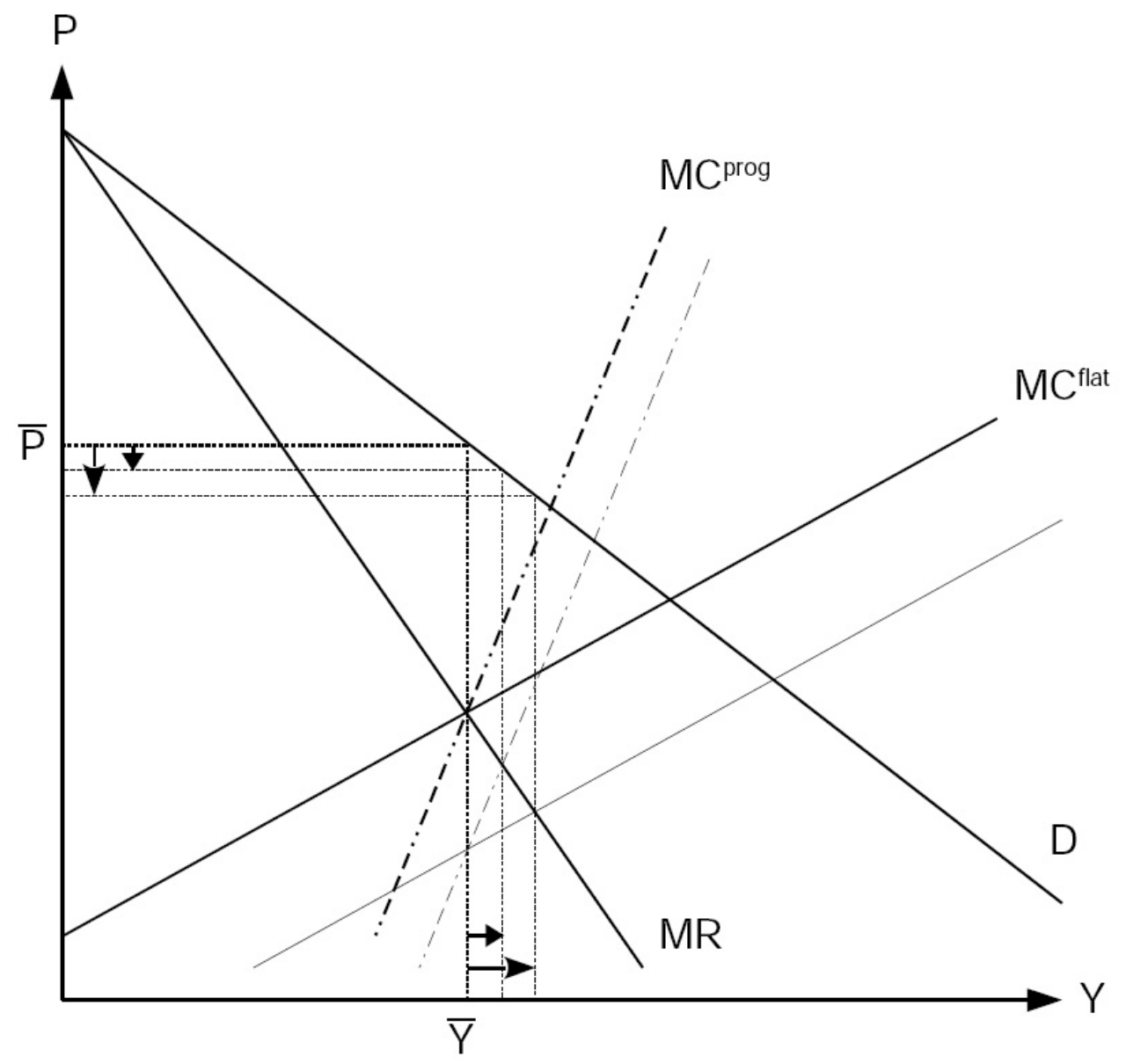


given fluctuations in technology will thus imply smaller movements of the (nominal) marginal cost schedule $M C$ along the marginal revenue schedule $M R$ (the bold $M C$ schedules in the figure apply when technology is at its steady state value). ${ }^{22}$ That is, the firm's output will fluctuate less around the steady state output $\bar{Y}$ when the tax system is progressive. These smaller output fluctuations then translate into smaller fluctuations of the firm's price around the steady state price $\bar{P}$. Aggregating over all firms, we can conclude that progressive taxes dampen fluctuations of the overall price level (i.e., the volatility of inflation is reduced) and of real GDP when technology shocks hit the economy.

At the same time, the greater degree of convexity of the marginal cost curve (which is, for simplicity, not shown in the figure) causes price decreases in the presence of positive productivity shocks to be smaller than the price increases in the presence of negative productivity shocks. This implies that the average price level rises. The intuition is the following: When productivity rises, marginal costs fall at the current level of output and firms are induced to reduce prices to boost demand in order to restore the optimal price markup. The opposite happens when a negative productivity shock hits the economy. In the former case, the real wage will rise and with it - more than proportionally - the marginal tax rate and marginal costs. In the latter case marginal costs will rise less than proportionally because of the progressive tax system. Price declines will thus be smaller than price increases in the presence of productivity shocks and average prices will thus be higher. This effect will matter in the dynamic setting discussed below where the interaction of inflation dynamics and monetary policy matters for equilibrium determination. $^{23}$

Finally, due to the dampening effect on output, progressive taxes increase the fluctuations of employment in the presence of technology shocks. ${ }^{24}$

Figure 2 sketches the firm's (optimal) response to government spending shocks, or more generally, demand shocks. ${ }^{25}$ We see that for given marginal cost schedules, fluctuations in demand imply smaller deviations of output from its steady state value when the marginal cost curve is steeper, i.e. when taxes are progressive. The figure also shows that as a consequence,

\footnotetext{
${ }^{22}$ For the sake of clarity, Figure 1 only shows the realization of a positive technology shock.

${ }^{23}$ Note that this effect is not captured when the model is only approximated to first order as was done by Mattesini and Rossi (2012).

${ }^{24}$ This is due to the well-known fact that in the presence of technology shocks output and employment move inversely when prices are sticky. Progressive taxes imply a smaller increase (decrease) in output after a positive (negative) technology shock and thus a larger decline (increase) in employment.

${ }^{25}$ Figure 2 shows the realization of a positive government spending shock.
} 
Figure 2: Demand shocks and volatility of output and prices

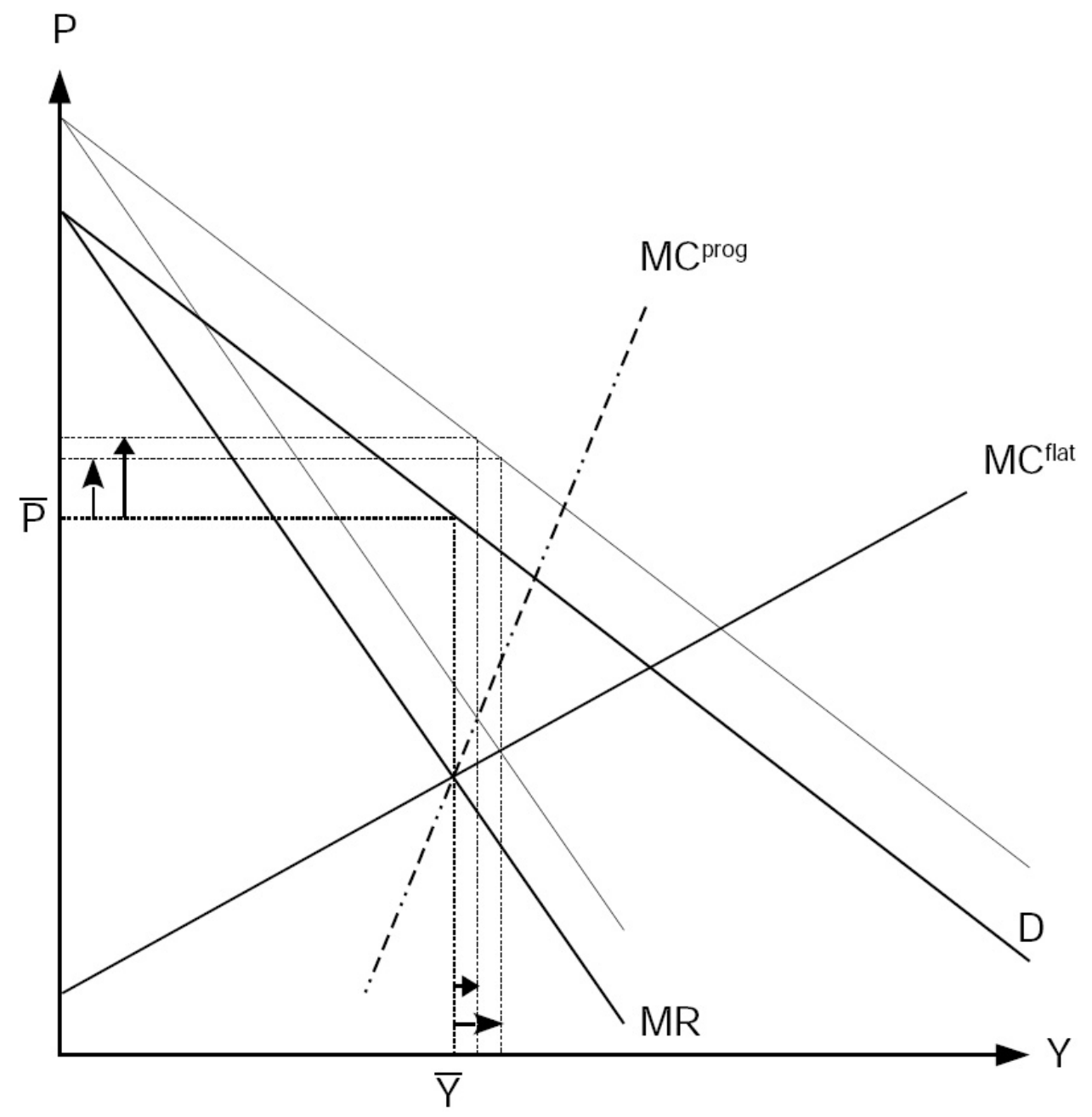


however, fluctuations of the optimally chosen price around its steady state value are larger. Aggregating over all firms, we infer that progressive taxes reduce the volatility of real GDP, relative to flat taxes, while increasing the volatility of inflation when demand shocks are present.

The convexity of the marginal cost schedule implies a higher average price level for demand shocks too. The shifts of the marginal revenue curve along the marginal cost curve imply price increases in response to positive demand shocks that are larger than the price decreases in response to negative demand shocks. The intuition for this is analogous to the case of productivity shocks. This price level effect will again matter in the dynamic setting discussed below.

At last, note that because employment and output move in the same direction after demand shocks hit the economy, progressive taxes also reduce fluctuations of employment.

\subsection{Progressive Taxation and Technology Shocks}

Let us now turn to the fully-fledged dynamic model which allows us to analyze the general equilibrium and welfare effects of progressive taxes. Table 1 presents business cycle statistics and the consumption loss equivalents of the simulated model when technology shocks are the only type of disturbance. In the first column, results for the baseline model with only Ricardian households are shown. Column two shows results where, in addition, rule-of-thumb households are considered. The table depicts the percentage change of the welfare losses $\xi$, the standard deviations of inflation, GDP, consumption, and employment as well as the aggregate levels of consumption and employment when moving from a flat to a progressive tax regime. Figure 3 displays impulse response functions for an expansionary productivity shock.

\subsubsection{Baseline model}

Table 1 shows that welfare rises when the progressive tax is introduced in the baseline model, the consumption loss equivalent falls by 14.3 percent. To understand this result, we first look at Figure 3 which provides important insights and complements the discussion in the static model.

An expansionary productivity shock causes a reduction in marginal costs and a fall in prices. This induces the central bank to lower the interest rate (not shown) and thereby the 
real rate to boost aggregate demand as it follows a Taylor-type rule. But this response will not be aggressive enough to raise consumption demand up to the point where marginal costs are perfectly stabilized. Hence, those firms that can adjust their prices will reduce them. Lastly, since aggregate demand does not rise as fast as aggregate supply, hours fall, a typical feature of New Keynesian models.

Table 1: Moments and Welfare Losses with Technology Shocks

\begin{tabular}{lcc}
\hline & without RoT & with RoT \\
\hline$\xi$ & -14.3 & +15.7 \\
$\xi^{A}$ & & +32.0 \\
$\xi^{N}$ & & -29.0 \\
$\sigma(\pi)$ & -12.1 & +4.4 \\
$\sigma(Y)$ & -12.1 & -12.1 \\
$\sigma(C)$ & -12.1 & -12.1 \\
$\sigma(N)$ & +64.0 & +63.5 \\
$\sigma\left(C^{A}\right)$ & & +4.3 \\
$\sigma\left(N^{A}\right)$ & & +63.5 \\
$\sigma\left(C^{N}\right)$ & & -34.1 \\
$\sigma\left(N^{N}\right)$ & & 0 \\
$C$ & -0.0004 & -0.001 \\
$N$ & +0.0002 & +0.001 \\
$C^{A}$ & & -0.00001 \\
$N^{A}$ & & +0.0021 \\
$C^{N}$ & & -0.0021 \\
$N^{N}$ & & 0 \\
\hline & & \\
\hline
\end{tabular}

Note: Results are changes compared to the flat-tax benchmark in percent.

As noted above, with a progressive income tax, the household labor supply curve and thus firms' marginal cost curves become steeper. It has been shown in the static setup that this implies that the positive productivity shock leads to a smaller decrease in marginal costs and therefore also to smaller price decreases by those firms that have the ability to adjust their prices in the current period. The central bank then reduces the policy rate and the real rate by less so that consumption demand increases are smaller while the reduction in hours worked 
Figure 3: Responses to Positive Productivity Shock
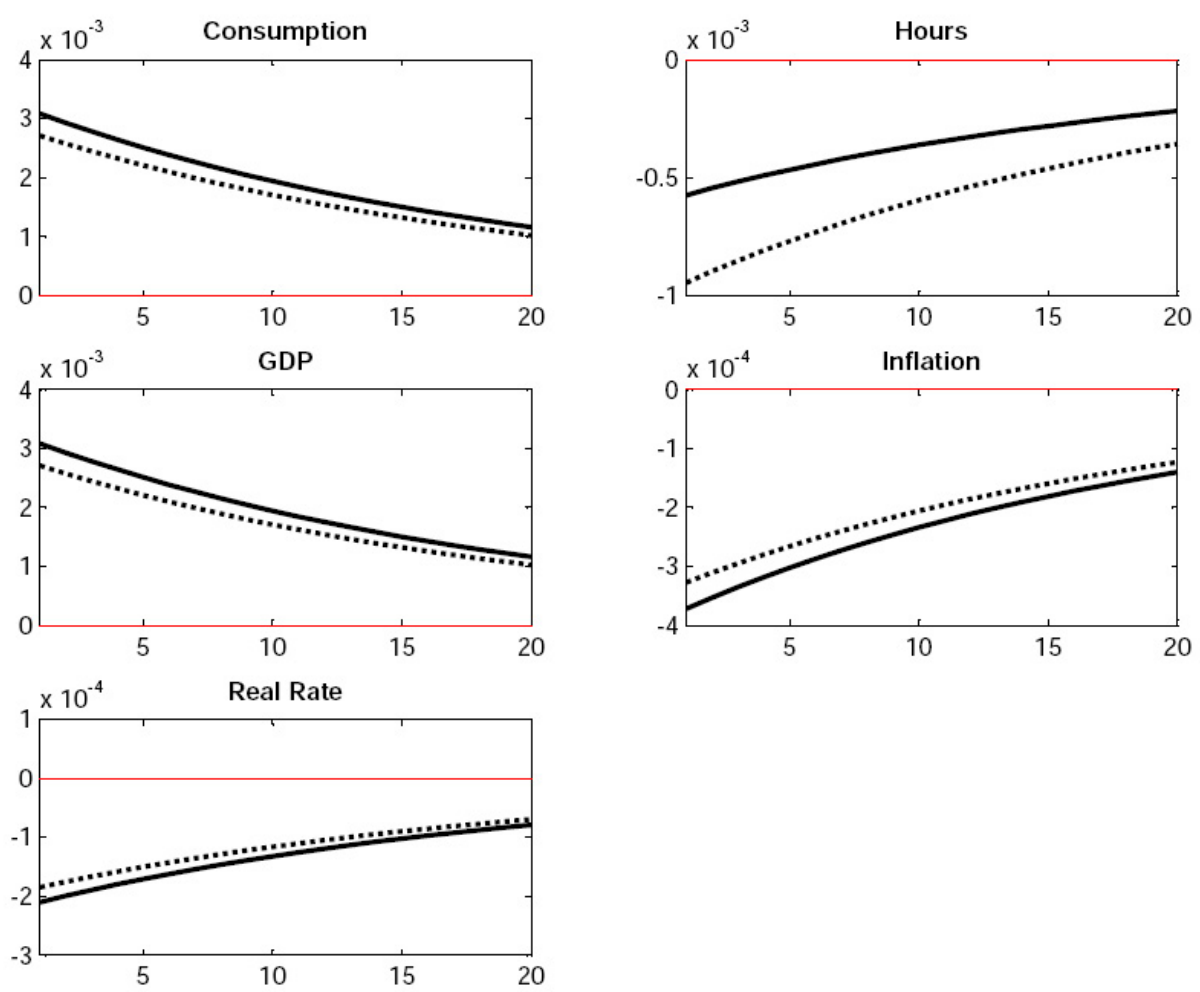

Note: Solid (dotted) lines indicate flat (progressive) taxes.

is more pronounced. All other things equal, the deflationary impact of the shock is thus lower and the increase in output and consumption is dampened. This is confirmed in Figure 3.

More generally, i.e. taking account of an entire history of positive and negative shocks to productivity, the volatilities of inflation, output and consumption are smaller and the volatility of hours is larger when taxes are progressive. As can be seen in Table 1, the standard deviation of domestic price inflation, output and consumption falls by about 12 percent each while the standard deviation of hours rises by 64 percent.

The last two rows of Table 1 next show the change in the average level of consumption and hours worked when progressive taxes are introduced. Consumption falls by 0.0004 percent while hours increase by 0.0002 percent. This is related to the effects of progressive taxes on the curvature of the real marginal cost function and its implications for the average inflation rate and the real rate of interest. As shown above, given productivity, the marginal cost function (10) does not only become steeper in output, it also becomes more convex when taxes are progressive. This implies that price increases in response to declining productivity will be greater than price decreases in response to rising productivity. The net effect is that prices will 
be set higher on average and the average inflation rate rises.

Higher average inflation, in turn, results in higher average real rates as the central bank follows the Taylor-type rule. Consequently, average consumption is lower. ${ }^{26}$ This lower consumption level increases the incentive to supply labor, average hours worked thus increase. ${ }^{27}$

Recall that the net effect of progressive taxes on welfare is determined by both its effect on the volatilities and the levels of consumption and hours. The level effects and the increased volatility of hours reduce welfare but these effects are dominated by the reduction in consumption volatility. The net effect in the baseline model is a 14.3 percent reduction of the consumption loss equivalent. In other words, tax progression causes a roughly 14 percent reduction in the welfare loss that is related to the stochastic environment.

To put our results in perspective, note that the traditional Keynesian macroeconomic motivation for progressive taxes is that they stabilize aggregate demand through stabilizing disposable income. It is evident that macroeconomic stabilization is achieved differently in our baseline economy. It is not the stabilization of disposable income that causes consumption and aggregate demand to be stabilized but the changed slope of the marginal cost function that dampens the volatility of the inflation rate and the real rate of interest.

In the next subsection, however, we assume the presence of rule-of-thumb households and thereby add the more traditional Keynesian channel of disposable income stabilization to our analysis. We will see that progressive taxation indeed improves welfare of rule-of-thumb households but we will also see that the above mechanism that improved welfare for Ricardian households breaks down and that their welfare therefore falls.

\subsubsection{Rule-of-thumb households}

As can be seen in Table 1, once rule-of-thumb households are considered, the welfare gains from progressive taxes no longer exist at the aggregate level. The consumption loss equivalent

\footnotetext{
${ }^{26}$ The level of consumption in any period of time can be computed by solving the consumption Euler equation forward. This results in an equation that relates current consumption to the entire history of future real interest rates which, taken together, can be interpreted as a long-term real interest rate. When this long-term real interest rate rises, consumption falls.

${ }^{27} \mathrm{~A}$ further effect of progressive taxes in our model is a direct consequence of the assumed concavity of the average tax schedule. In the presence of (real) wage income volatility, a concave average tax schedule will reduce the household's average wage income tax rate (relative to a flat tax) since the additional tax burden resulting from above-average income realizations is smaller than the tax relief due to below-average realizations. All other things equal, the progressive tax thus reduces the average tax distortion when wage income is stochastic and thus further increases the incentive to work. However, this effect is negligible in our model since the results do not change when using a linear progressive tax schedule instead.
} 
rises by 15.7 percent. Progressive taxes thus cannot be recommended from a strictly utilitarian point of view.

This important (and at first sight somewhat counterintuitive) deviation from the baseline model is driven by the influence of the progressive tax on rule-of-thumb households' consumption demand and thereby aggregate demand: tax progression significantly reduces the volatility of disposable income and consumption of these households and thereby dampens aggregate demand fluctuations. More precisely, aggregate demand rises (falls) less in the face of expansionary (contractionary) productivity shocks resulting in bigger price reductions (increases) by firms. The volatility of inflation and hence the real rate of interest increases, boosting, in turn, the volatility of the Ricardian household's consumption. The two households' consumption volatilities thus move in opposite directions when progressive taxes are introduced.

At the same time, no matter how progressive the tax system is, the volatility of hours worked is zero for rule-of-thumb households as income and substitution effects cancel each other out for the log utility case $(\sigma=1)$ that we consider here. The Ricardian household, in contrast, suffers from a higher employment volatility when progressive taxes are introduced (like in the benchmark specification without rule-of-thumb households). Because the effects on average employment and consumption demand are small in the current setting too, the volatility effects therefore again dominate the welfare effects of tax progression: the Ricardian household's consumption equivalent rises by 32 percent while the rule-of-thumb household's equivalent decreases by 29 percent. We thus observe a huge distributional effect in favor of rule-of-thumb households. ${ }^{28}$

\subsection{Progressive Taxation and Government Spending Shocks}

Table 2 presents the business cycle and welfare effects of progressive taxation when government spending shocks are the only type of disturbance in the economy. As before, results for the baseline model with only Ricardian households are displayed in the first column. Column two again displays results where rule-of-thumb households are included.

\footnotetext{
${ }^{28}$ Assuming $\sigma \neq 1$ instead does not change these results. In this case, rule-of-thumb employment is volatile, but progressive taxation leads to a reduced volatility. As for $\sigma=1$, progressive taxation leads to an increase in the volatility of Ricardian employment.
} 
Table 2: Moments and Welfare Losses with Spending Shocks

\begin{tabular}{lcc}
\hline & without RoT & with RoT \\
\hline$\xi$ & +20.2 & +40.7 \\
$\xi^{A}$ & & +53.0 \\
$\xi^{N}$ & & +10.0 \\
$\sigma(\pi)$ & +35.3 & +31.0 \\
$\sigma(Y)$ & -14.5 & -17.3 \\
$\sigma(C)$ & +35.3 & +239.3 \\
$\sigma(N)$ & -14.5 & -17.3 \\
$\sigma\left(C^{A}\right)$ & & +31.0 \\
$\sigma\left(N^{A}\right)$ & & -17.3 \\
$\sigma\left(C^{N}\right)$ & & -13.5 \\
$\sigma\left(N^{N}\right)$ & & 0 \\
$C$ & -0.00026 & -0.001 \\
$N$ & +0.00004 & +0.001 \\
$C^{A}$ & & -0.003 \\
$N^{A}$ & & +0.001 \\
$C^{N}$ & & -0.0003 \\
$N^{N}$ & & 0 \\
\hline & & \\
\hline
\end{tabular}

Note: Results are changes compared to the flat-tax benchmark in percent.

\subsubsection{Baseline model}

Table 2 shows that there are no welfare gains when progressive taxes are introduced in the baseline model. The consumption loss equivalent rises by 20.2 percent. To understand this important result, we first look at Figure 4 which depicts impulse response functions to an expansionary spending shock.

We observe that the shock increases aggregate demand and thus hours worked in the economy. This additional labor demand causes an increase in marginal costs, inflation, and the real rate of interest which induces a reduction in private consumption. Over the cycle, this increased volatility in consumption and hours clearly reduces welfare compared to the deterministic steady state. 
Figure 4: Responses to Positive Spending Shock
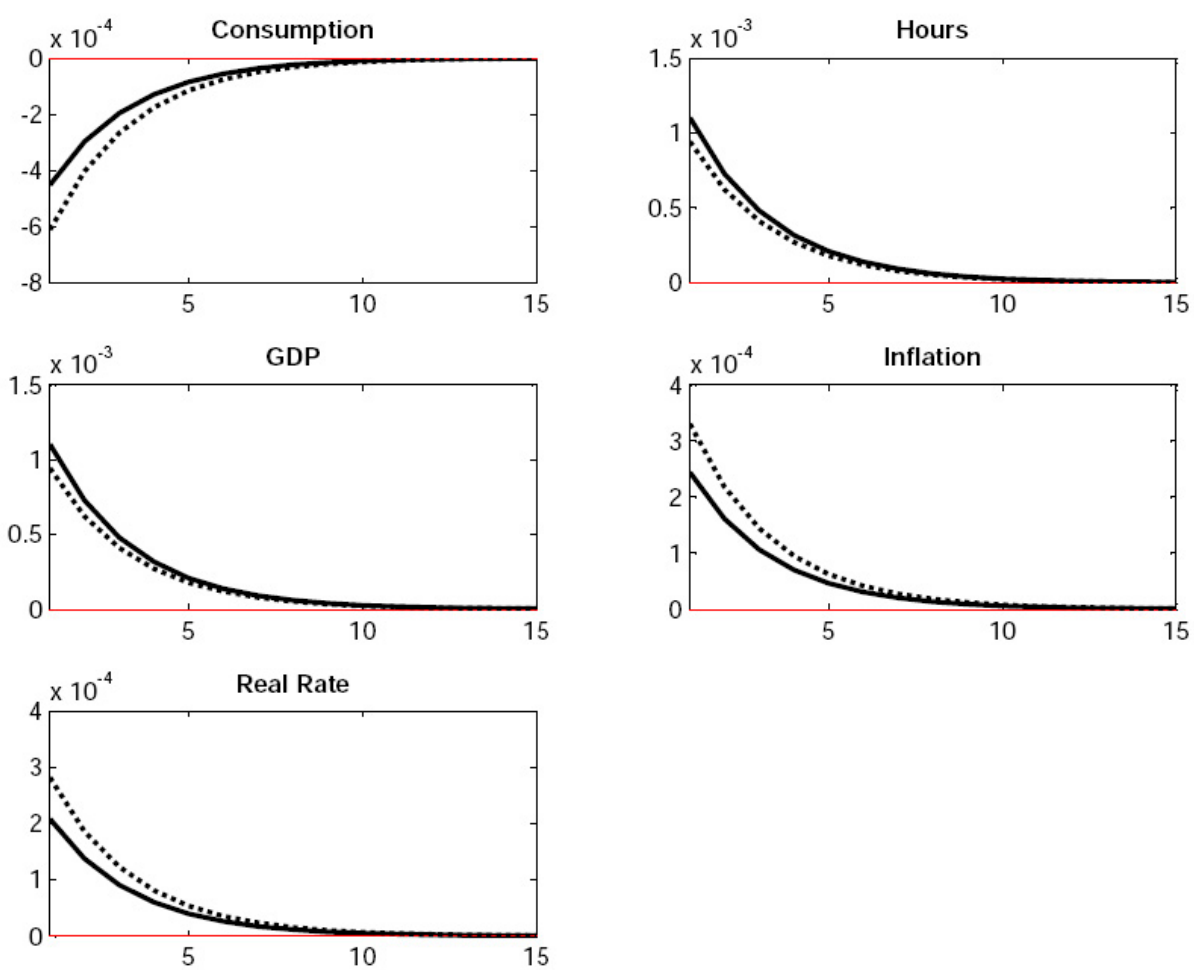

Note: Solid (dotted) lines indicate flat (progressive) taxes.

With a progressive tax system, the steeper marginal cost curve implies, for a given increase in demand by the government, an even larger increase in marginal costs and consequently stronger inflationary pressure (just as in the static analysis). We consequently observe a higher real interest rate as well as more crowding-out of private consumption. Due to the smaller increase in demand and output, however, hours worked rise less. Over the cycle, a lower volatility of hours is thus traded off against a higher volatility of consumption. At the same time, as explained in section 4.1, the increased curvature of the marginal cost function again implies a higher average inflation rate, a higher real interest rate, and hence a lower level of consumption. The lower average consumption level finally increases the incentive to supply labor resulting in more hours worked on average.

In terms of welfare, the two level effects and the increased volatility of consumption thus dominate the lower volatility of hours. Notice, yet, that the level effects are again rather small. Hence, as with productivity shocks, it is mostly how the progressive tax affects the volatility of consumption that matters for household welfare. 


\subsubsection{Rule-of-thumb households}

Table 2 shows that there are also no welfare gains under tax progression when rule-of-thumb households are present. On the contrary, the increase in the consumption loss equivalent is even larger than in the baseline model (40.7 percent).

To understand this result, notice that the inflationary pressure caused by an expansionary government spending shock can only be countered by the central bank through raising the real interest rate and thereby inducing the Ricardian household to lower its consumption demand. In contrast, the rule-of-thumb household does not respond to the higher real rate. Instead, it responds to its higher current period income (a result of the increase in labor demand and hence real wages) by increasing its consumption. Aggregate demand is therefore reduced to a lower extent for a given change in the real rate, inflation rises more, and accordingly, the real rate needs to be increased more too. The Ricardian household thus needs to bear a bigger burden of the adjustment and experiences a larger drop in consumption than in the scenario without the rule-of-thumb household. Over the cycle, by implication, its consumption volatility rises. Furthermore, as the rule-of-thumb household's hours worked are constant, the Ricardian household's hours also fluctuate more compared to the scenario without rule-of-thumb households.

Turning to the role of the progressive tax system, the increase in the rule-of-thumb household's consumption demand in response to the expansionary spending shock is dampened when the average tax rate increases in income. All other things equal, the inflationary pressure is reduced. But the results in table Table 2 imply that this effect is more than offset by the effects of the steeper and more convex marginal cost curve on the rate of inflation: As a consequence of the stronger inflationary pressure due to the tax progression, the central bank needs to raise the real interest rate by more to achieve a larger crowding-out of the Ricardian household's consumption. Over the cycle, Ricardian consumption volatility thus rises and Ricardian welfare falls. Furthermore, and in contrast to productivity shocks, the rule-of-thumb household's welfare falls too: the higher average rate of inflation caused by the convexity of the marginal cost curve reduces the average level of their consumption which, in this case, dominates the effect of a lower consumption volatility. The stabilization of income and consumption thus does not improve the rule-of-thumb household's welfare. This remarkable result implies that 
the non-linear supply side effects can turn around the conventional case for progressive taxes based on demand side income stabilization.

\subsection{Optimal Tax Progression}

The previous analysis has shown that progressive taxes improve welfare in the baseline economy when technology shocks hit the economy, they decrease welfare, however, in the presence of government spending shocks. When running the simulations we took the degree of tax progressivity as a given, i.e. we fixed $\phi_{n}$ at the value 0.34 , the empirically observed average of the EA-12 countries. In this section, instead, we examine what the optimal degree of tax progression in our baseline model economy is. For this purpose, we let the coefficient of tax progression vary between the values 0 and 0.8 and compute household welfare in the presence of technology shocks, government spending shocks, and both shock types. ${ }^{29}$

Our calculations reveal that welfare uniformly increases in $\phi_{n}$ when only technology shocks are considered (not shown). In contrast, welfare uniformly decreases when only government spending shocks are considered (not shown), i.e. the optimal degree of tax progression is zero in this case. Consequently, when allowing for both shock types, the optimal degree of tax progression depends on the relative importance of these shocks in driving the business cycle. As can be seen in Figure 5, for our (shock) calibration, the optimum of the progressivity parameter $\phi_{n}$ is found at roughly the value 0.55 . From a macroeconomic stabilization perspective, at least through the lens of our baseline model, it seems that the average EA-12 country could increase household welfare by increasing the degree of tax progression. Notice, however, that the optimal progression for the model with rule-of-thumb households is zero.

\section{Extensions}

We make two model extensions in this section. Since the focus of our analysis is on the Eurozone economies, we first check whether our results also hold up in the more realistic, yet somewhat less tractable setting of a currency union. Secondly, we check how an optimal conduct of monetary policy affects the previous results.

\footnotetext{
${ }^{29}$ Note that the highest observed value for $\phi_{n}$ by Mattesini and Rossi (2012) in a sample of 24 OECD countries is 0.66 for the Netherlands.
} 
Figure 5: Welfare and Tax Progression

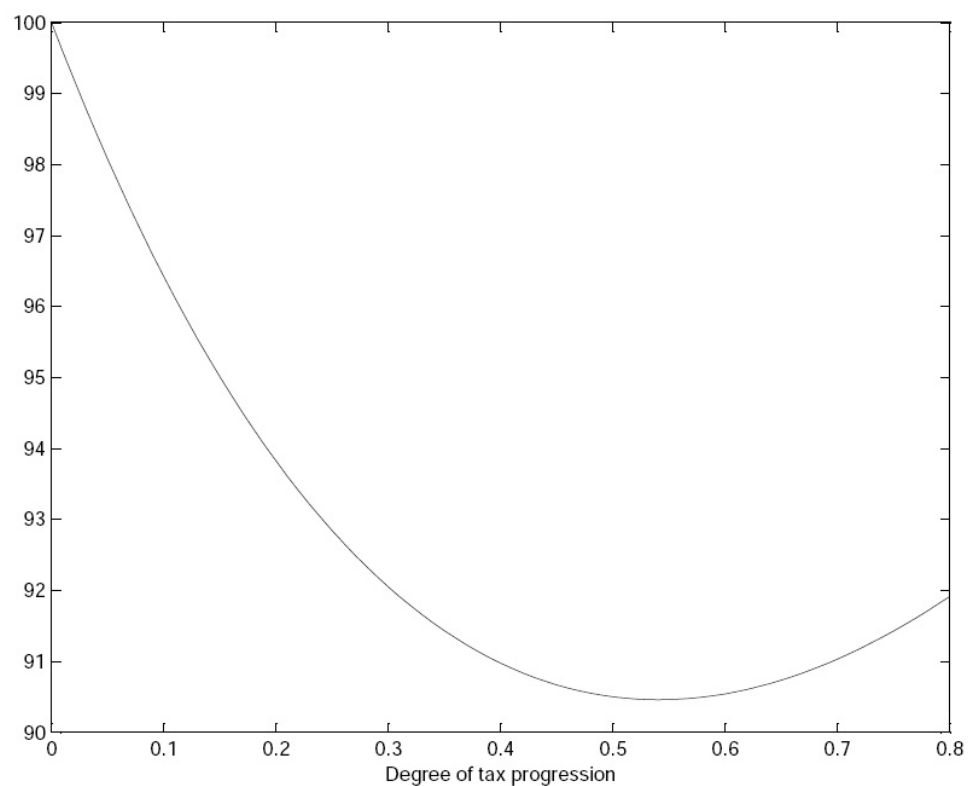

Note: The welfare loss under the flat tax is normalized to 100.

\subsection{Currency Union}

To simplify matters, we assume that the currency union consists of only two countries, Home and Foreign, with relative sizes $(1-n)$ and $n$, respectively. In the following, for the sake of brevity, we only depict the model elements that differ from the closed economy setup. ${ }^{30}$

Households consume both domestic and foreign goods. More precisely, the Home consumption aggregate combines Home and Foreign consumption baskets according to

$$
C_{t}=\left[\left(1-\omega^{H}\right)^{\frac{1}{\theta}}\left(C_{t}^{H}\right)^{\frac{\theta-1}{\theta}}+\left(\omega^{H}\right)^{\frac{1}{\theta}}\left(C_{t}^{F}\right)^{\frac{\theta-1}{\theta}}\right]^{\frac{\theta}{1-\theta}}
$$

where $\omega^{H}$ determines the import share of household consumption and $\theta$ the elasticity of substitution between Home $\left(C_{t}^{H}\right)$ and Foreign $\left(C_{t}^{F}\right)$ baskets. These baskets are aggregators given by

$$
\begin{aligned}
& C_{t}^{H}=\left[(1-n)^{-\frac{1}{\epsilon}} \int_{n}^{1}\left(C_{t}^{H}(i)\right)^{\frac{\epsilon-1}{\epsilon}} d i\right]^{\frac{\epsilon}{\epsilon-1}} \\
& C_{t}^{F}=\left[n^{-\frac{1}{\epsilon}} \int_{0}^{n}\left(C_{t}^{F}(i)\right)^{\frac{\epsilon-1}{\epsilon}} d i\right]^{\frac{\epsilon}{\epsilon-1}}
\end{aligned}
$$

where $C_{t}^{H}(i)$ denotes the good produced by firm $i \in[n, 1]$ located in country $H$ and $C_{t}^{F}(i)$ the

\footnotetext{
${ }^{30}$ The complete model equations are available from the authors upon request.
} 
good produced by firm $i \in[0, n]$ located in country $F$. Equivalent expressions for the three aggregators apply to the Foreign economy.

We further assume that Home and Foreign (Ricardian) households can trade an international (riskless) bond. The corresponding interest rate is equal to the central bank policy rate. We thus allow the current account to move into surplus or deficit in response to economic shocks.

At last, monetary policy is set at the union-level. The common central bank follows a Taylor-type rule that targets a weighted average of Home and Foreign price inflation and is given by

$$
R_{t}=\beta^{-1}\left(\left(\frac{P_{t}^{H}}{P_{t-1}^{H}}\right)^{1-n}\left(\frac{P_{t}^{F}}{P_{t-1}^{F}}\right)^{n}\right)^{\phi_{\pi}}
$$

with $P_{t}^{H}=\left((1-n)^{-1} \int_{n}^{1} P_{t}^{H}(i)^{1-\epsilon} d i\right)^{\frac{1}{1-\epsilon}}$ and $P_{t}^{F}=\left(n^{-1} \int_{0}^{n} P_{t}^{F}(i)^{1-\epsilon} d i\right)^{\frac{1}{1-\epsilon}}$ denoting the Home and Foreign price levels, respectively.

Fiscal policy is set, as before, at the national level.

Turning to the model calibration, we assume that Home and Foreign are of equal size, i.e. $n=0.5$. Both countries exhibit the same degree of tax progression $\left(\phi_{n}=0.34\right)$. The elasticity of substitution between Home and Foreign consumption baskets is assumed to be $\theta=2$ as in Obstfeld and Rogoff (2005) and Nakamura and Steinsson (2014). For the home bias we set $\omega^{H}=\omega^{F}=0.2$. The standard deviations of the innovations $\epsilon$ are assumed to be the same for both countries and again chosen so as to match the observed volatility of GDP and government purchases in the Eurozone. The values are 0.00343 for technology shocks and 0.0062 for government spending shocks. For simplicity, the shocks are assumed to be uncorrelated across countries. Finally, we set international bond holdings in the steady state to zero.

Table 3 confirms that our previous results for the baseline model carry over, at any rate in qualitative terms, to the currency union setting. ${ }^{31}$ Progressive taxes again increase (decrease) welfare in the presence of technology (government spending) shocks, the direction of the level and volatility effects is also as before. Yet we observe that the percentage changes in the consumption loss equivalents are somewhat smaller, i.e. the relative welfare gains (losses) when

\footnotetext{
${ }^{31}$ For the sake of brevity, we do not discuss the model with rule-of-thumb households here because results also do not change qualitatively. The results are available from the authors upon request.
} 
moving from flat to progressive taxes under technology (government spending) shocks are a bit smaller than in the closed economy case.

Table 3: Moments and Welfare Losses: Currency Union vs. Closed Economy

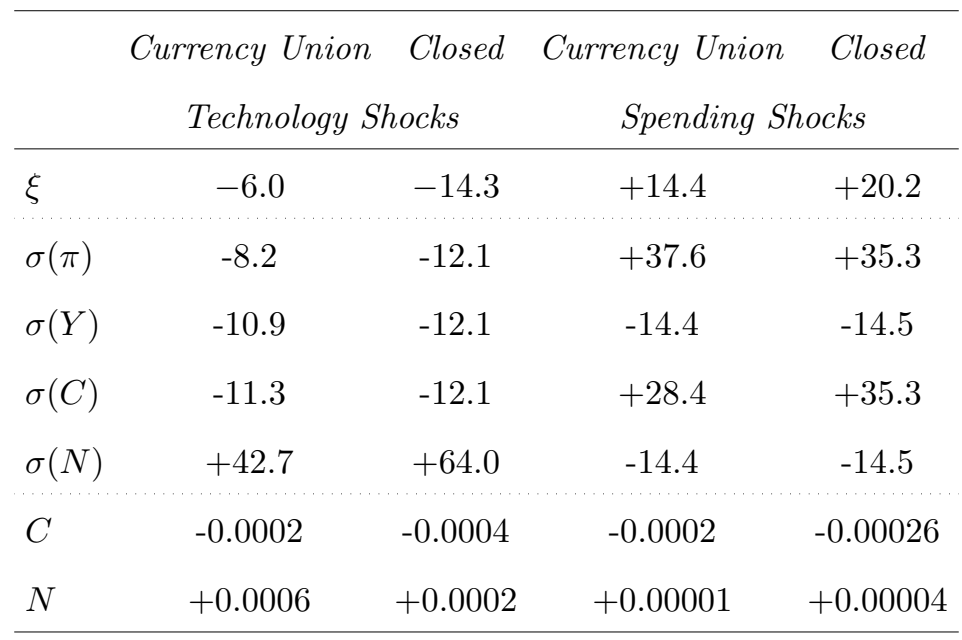

Note: Results are changes compared to the flat-tax benchmark in percent.

The main quantitative differences compared to the closed economy arise from the movement of the terms of trade and hence the trade balance. Consider the responses to a positive technology shock first (Figure 6). The terms of trade depreciate allowing exports and output to increase initially and thereby smooth consumption better than in the closed economy. As prices adjust only in a staggered fashion, the terms of trade depreciation lasts for several quarters causing output to increase in a hump shaped manner (in contrast to the closed economy). This prompts employment to rapidly return to the steady state level after a sharp initial drop. This initial drop is larger than in the closed economy because the central bank reacts less vigorously to this country specific shock than the national central bank in a closed economy.

The key to understanding the role of progressive taxes in the currency union setting is to realize that the reduced inflation volatility, resulting from progression (see above), also decreases the volatility of the terms of trade. Expenditure switching between Home and Foreign is therefore mitigated and with it the key mechanism for consumption smoothing in an open economy. All other things equal, the relative reduction in consumption volatility due to tax progression should therefore be smaller than in the closed economy setting. And so should be, consequently, the relative reduction in the consumption loss equivalent. Both points are 
Figure 6: Responses to Positive Technology Shock
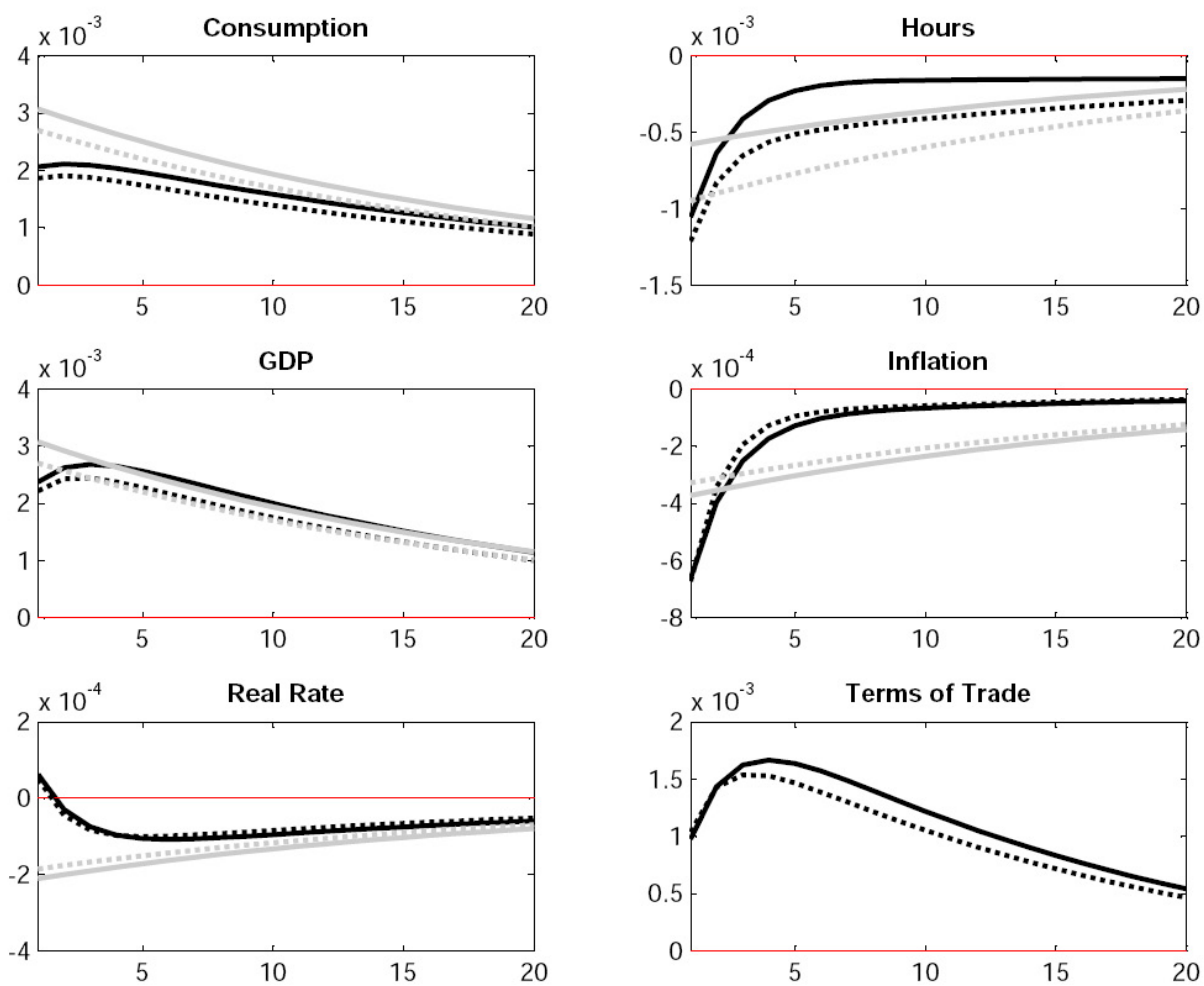

Note: Solid (dotted) lines indicate flat (progressive) taxes. Grey lines depict the closed economy case.

confirmed in Table 3.

Figure 7 next depicts impulse responses to a positive government spending shock. The responses look fairly similar to those of the closed economy setup. However, the main difference is that the shock affects the terms of trade. The (Home) terms of trade first rise above its steady state value before reversing after a couple of quarters. This initial increase causes a decline in net exports. Put otherwise, Home households maintain a higher consumption level than in the closed economy by drawing on relatively cheap Foreign resources.

As in the closed economy, the progressive tax system increases the volatility of the inflation rate. This in turn increases the volatility of the terms of trade and therefore leads to more expenditure switching between Home and Foreign. As a result, the relative increase in consumption volatility and thus the consumption loss equivalent due to tax progression should be somewhat reduced in the currency union setting. This is confirmed in Table 3.

Summing up, in a currency union the progressive tax system is less beneficial for productivity shocks and less harmful for demand shocks. However, the existence of rule-of-thumb households 
Figure 7: Responses to Positive Spending Shock
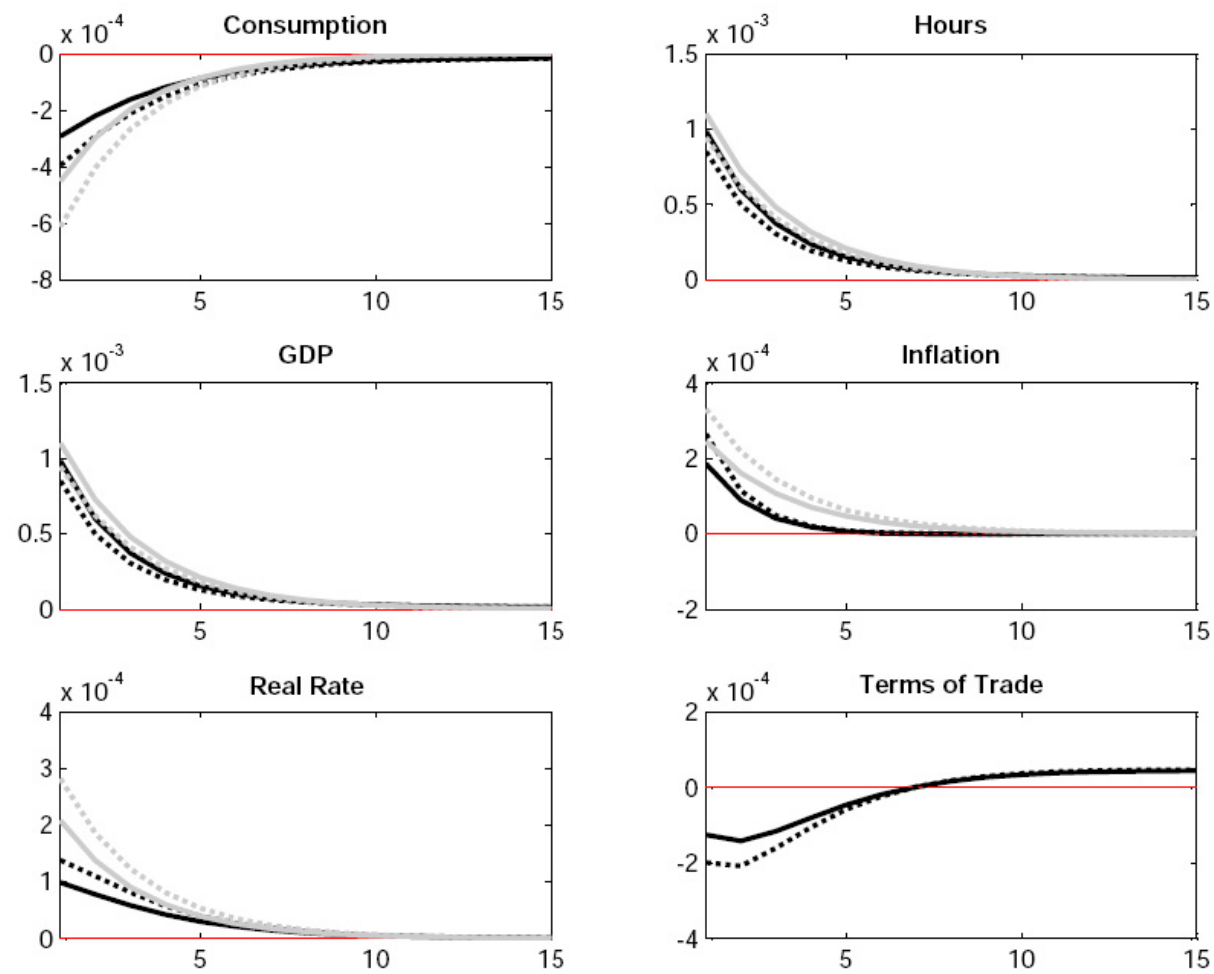

Note: Solid (dotted) lines indicate flat (progressive) taxes. Grey lines depict the closed economy case.

removes any utilitarian benefits, just like in the closed economy setting, so that the overall conclusion from the closed economy setting remains intact.

\subsection{Optimal Monetary Policy}

Most advanced economies achieve macroeconomic stabilization primarily through changes in the monetary policy stance. In this section, we analyze whether a progressive tax system is a reasonable addition to the macroeconomic stabilization toolkit, i.e. whether it improves economic welfare, once the principal stabilization tool, monetary policy, is conducted optimally. In what follows, we only consider the baseline model with technology shocks since for the other specifications progressive taxes did not result in welfare improvements even under the Taylortype rule. It should therefore be clear that a distortionary tax cannot improve welfare when monetary policy is conducted optimally. ${ }^{32}$ Also note that the central bank's objective function is household welfare and that this objective function is maximized taking the optimality conditions of households and firms as given.

\footnotetext{
${ }^{32}$ Results are of course available from the authors upon request.
} 
It will be easier to understand the subsequent results by first remembering what the optimal monetary policy aims for in the standard New Keynesian model without tax progression. The goal of optimal monetary policy is to eliminate inflation and thereby inefficient price dispersion between firms. This is achieved by a much more aggressive reduction of the real interest rate in response to a positive productivity shock (relative to the Taylor-type rule considered in section 4). Over the cycle, the real rate and the Ricardian household's consumption are thus more volatile while the volatility of hours worked falls. The elimination of price dispersion increases aggregate productivity as can be seen from equation (9) and thereby average consumption. The higher average consumption level in turn induces the household to work less hours.

Table 4: Moments and Welfare Losses: Optimal Monetary Policy vs. Taylor Rule

\begin{tabular}{lcc}
\hline & Optimal Policy & Taylor Rule \\
\hline$\xi$ & +7.1 & -14.3 \\
\hdashline$\sigma(\pi)$ & +256.7 & -12.1 \\
$\sigma(Y)$ & -12.7 & -12.1 \\
$\sigma(C)$ & -12.7 & -12.1 \\
$\sigma(N)$ & +76.2 & +64.0 \\
$C$ & -0.0019 & -0.0004 \\
$N$ & +0.00001 & +0.0002 \\
\hline
\end{tabular}

Note: Results are changes compared to the flat-tax benchmark in percent.

To understand how the progressive tax affects welfare in the presence of optimal monetary policy, recall that the increase in welfare due to the introduction of the progressive tax under the Taylor rule was caused by a smaller consumption volatility and a higher volatility of hours while the level of consumption fell and hours increased. These effects still holds under the optimal monetary policy. All four moments are thus shifted in the "wrong" direction by the progressive taxes. This can be verified in Table 4. Progressive taxes are thus only welfare enhancing once monetary policy is not conducted optimally. 


\section{Conclusion}

Using a non-linear New Keynesian DSGE model, we find that a progressive tax on wage income can improve welfare only under a rather narrow set of circumstances. We show that progressive taxes improve aggregate welfare in the presence of technology shocks, but only when rule-ofthumb households are absent and monetary policy is not conducted optimally. When rule-ofthumb households are added and/or demand shocks are considered, no welfare gains exist at the aggregate level. However, in the presence of technology shocks, progressive taxes improve the welfare of rule-of-thumb households.

In conclusion, we want to point to a number of assumptions made in our approach, some of which may warrant further research. First, we concentrate only on the business cycle effects of tax progression. There are sizable, and well known, negative effects on the steady state allocation which we abstract from by introducing an employment subsidy which perfectly offsets the labor discouraging effect of tax progression. The advantage of our approach is that we are able to compare the business cycle effects of a flat and a progressive tax and do not mix up steady state and business cycle effects.

Second, we make the assumption that both households have an identical consumption and thus utility level in the deterministic steady state. It is conceivable that the result of a negative effect of progressive taxes on aggregate welfare under technology shocks can be overturned by assuming, not implausibly in our view, a higher steady state consumption and utility level for Ricardian households (relative to rule-of-thumb households). The reason is that a higher consumption level might reduce the impact of the increase in the Ricardian's consumption volatility, caused by the progressive tax when rule-of-thumb households are present, on welfare.

Third, we assume log-utility in consumption which results in a constant labor supply of rule-of-thumb households. Our approach thus requires the entire burden of adjustment of the labor input to be borne by Ricardian households. This is likely to exacerbate the negative welfare effect of progressive taxes on the latter type of households. Further research seems warranted to better grasp the interaction on the labor market. 


\section{References}

[1] Auerbach, A. J., Feenberg, D., 2000. The Significance of Federal Taxes as Automatic Stabilizers. Journal of Economic Perspectives 14 (3), 37-56.

[2] Benes, J., Kumhof, M., 2011. Risky Bank Lending and Optimal Capital Adequacy Regulation. IMF Working Papers 11/130.

[3] Brown, E. C., 1955. The Static Theory of Automatic Fiscal Stabilization. Journal of Political Economy 63 (5), 427-440.

[4] Calvo, G., 1983. Staggered Prices in a Utility Maximizing Framework. Journal of Monetary Economics 12, 383-398.

[5] Chen, S.-H., Guo, J.-T., 2013. Progressive taxation and macroeconomic (In) stability with productive government spending. Journal of Economic Dynamics and Control 37, 951-963.

[6] Chen, S.-H., Guo, J.-T., 2014. Progressive taxation and macroeconomic (in)stability with utility-generating government spending. Journal of Macroeconomics 42, 174-183.

[7] Christiano, L. J., Eichenbaum, M., Evans, C. L., 2005. Nominal Rigidities and the Dynamic Effects of a Shock to Monetary Policy. Journal of Political Economy 113 (1), 1-45.

[8] Galí, J., 2008. Monetary Policy, Inflation, and the Business Cycle: An Introduction to the New Keynesian Framework. Princeton University Press, Princeton, NJ.

[9] Galí, J., Lopéz-Salido, J. D., Vallés, J., 2004. Rule-of-Thumb Consumers and the Design of Interest Rate Rules. Journal of Money, Credit and Banking 36 (4), 739-764.

[10] Galí, J., Lopéz-Salido, J. D., Vallés, J., 2007. Understanding the Effects of Government Spending on Consumption. Journal of the European Economic Association 5 (1), 227-270.

[11] Guo, J.-T., Lansing, K. J., 1998. Indeterminacy and Stabilization Policy. Journal of Economic Theory 82, 481-490.

[12] Hayo, B., Hofmann, B., 2006. Comparing Monetary Policy Reaction Functions: ECB versus Bundesbank. Empirical Economics 31, 645-662. 
[13] Kameník, O., 2011. DSGE Models with Dynare++. A Tutorial. Mimeo.

[14] Krusell, P., Smith, A. A. Jr., 1998. Income and Wealth Heterogeneity in the Macroeconomy. Journal of Political Economy 106 (5), 867-896.

[15] Lucas, R. E. Jr., 1987. Models of Business Cycles. Basil Blackwell, Oxford, New York.

[16] Mankiw, N. G., 2000. The Savers-Spenders Theory of Fiscal Policy. American Economic Review 90, 120-125.

[17] Mattesini, F., Rossi, L., 2012. Monetary Policy and Automatic Stabilizers: the Role of Progressive Taxation. Journal of Money, Credit and Banking 44 (5), 825-862.

[18] McKay, A., Reis, R., 2016a. The Role of Automatic Stabilizers in the U.S. Business Cycle. Econometrica 84 (1), 141-194.

[19] McKay, A., Reis, R., 2016b. Optimal Automatic Stabilizers. NBER Working Paper No. 22359.

[20] Nakamura, E., Steinsson, J., 2014. Fiscal Stimulus in a Monetary Union: Evidence from U.S. Regions. American Economic Review 104 (3), 753-792.

[21] Obstfeld, M., Rogoff, K., 2005. Global Current Account Imbalances and Exchange Rate Adjustments. Brookings Papers on Economic Activity, 67-146.

[22] Schmitt-Grohé, S., Uribe, M., 2006. Optimal Simple and Implementable Monetary and Fiscal Rules: Expanded Version. NBER Working Papers 12402.

[23] Taylor, J. B., 1993. Discretion versus Policy Rules in Practice. Carnegie-Rochester Series on Public Policy 39, 195-214.

[24] Woodford, M., 2003. Interest and Prices: Foundations of a Theory of Monetary Policy. Princeton University Press, Princeton, NJ. 